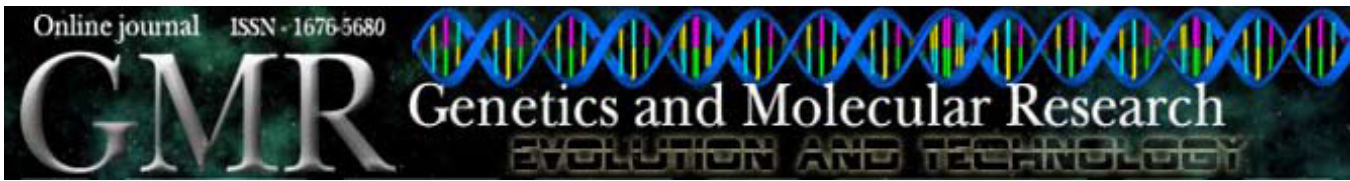

\title{
An efficient protocol for tissue sampling and DNA isolation from the stem bark of Leguminosae trees
}

\author{
R.M.L. Novaes, J.G. Rodrigues and M.B. Lovato \\ Departamento de Biologia Geral, Instituto de Ciências Biológicas, \\ Universidade Federal de Minas Gerais, Belo Horizonte, MG, Brasil \\ Corresponding author: M.B. Lovato \\ E-mail: lovatomb@icb.ufmg.br / milagresnovaes@gmail.com
}

Genet. Mol. Res. 8 (1): 86-96 (2009)

Received October 10, 2008

Accepted October 17, 2008

Published February 3, 2009

\begin{abstract}
Traditionally, molecular studies of plant species have used leaves as the source of DNA. However, sampling leaves from tall tree species can be quite difficult and expensive. We developed a sequence of procedures for using stem bark as a source of DNA from Leguminosae trees of the Atlantic Forest and the Cerrado. Leguminosae is an important species-rich family in these two highly diverse and endangered biomes. A modified CTAB protocol for DNA isolation is described, and details of the procedures for sampling and storage of the bark are given. The procedures were initially developed for three species, and then their applicability for 15 other species was evaluated. DNA of satisfactory quality was obtained from the bark of all species. The amounts of DNA obtained from leaves were slightly
\end{abstract}


higher than from bark samples, while its purity was the same. Storing the bark frozen or by drying in silica gel yielded similar results. Polymerase chain reaction amplification worked for both plastid and nuclear genomes. This alternative for isolating DNA from bark samples of trees facilitates field work with these tree species.

Key words: DNA isolation; Bark; Trunk; Cambium; Trees; Leguminosae

\section{INTRODUCTION}

The number of biodiversity studies using molecular approaches, such as population genetics and molecular systematics, has increased considerably (e.g., Avise, 2000; Crawford, 2000). Typically, studies involving plant species have used leaves as the main source of DNA. However, sampling leaves from tall tree species can be a very laborious task and can pose a major obstacle to efficient and fast field work desirable for these studies.

Different problems can arise when depending on leaves as the only source of DNA. Among the procedures commonly used to reach the leaves of tall trees are the use of very long tree pruners or firearms and even the employment of specialized tree climbers. These procedures have several drawbacks: mainly, they can be too time-consuming, can have substantial costs and can be unavailable in some instances. During rainy days, they can be even more prohibitive, making field work sometimes impossible. The other common problem concerns the availability and quality of the leaves. Deciduous and semideciduous tree species can have all their leaves lost or senescent during the dry season, making the sampling of leaves in this period impossible. Moreover, if leaves are severely attacked by microbes, fungi or small invertebrates, producing secondary metabolites such as alkaloids (Coley and Barone, 1996), DNA isolation and its quality may be compromised. Finally, DNA from these organisms could be co-extracted with the plant DNA and affect further analysis. All these common problems could be easily overcome with the sampling of the stem bark from trees for DNA-based studies. In contrast to leaves, bark can usually be easily sampled from the ground level, with simple tools and in a relatively short time, and is available during all the year.

Stem bark comprises all tissues outside the vascular cambium, and in secondary states, as in tree trunks, includes the phloem, the periderm and the dead tissues outside the periderm. Among these tissues, the phloem is the best candidate for DNA isolation, as it has the greatest amount of live cells in the bark (Esau, 1977). The bark tissues can have different compounds in relation to the leaves and, due to phloem presence, can be especially rich in sugars, which are known to be a problem in plant DNA isolation and to downstream applications (Fang et al., 1992; Pandey et al., 1996). Several protocols have been developed for plant DNA isolation (e.g., Rogers and Bendich, 1985; Doyle and Doyle, 1987; Csaikl et al., 1998; Ribeiro and Lovato, 2007; Ivanova et al., 2008), but few of them have addressed the problem of extracting DNA from trunk tissues, such as bark (e.g., Colpaert et al., 2005; Rachmayanti et al., 2006; Tibbits et al., 2006). Most of the commercial kits for plant DNA isolation have been designed for leaves, and usually 
for model species (e.g., DNeasy ${ }^{\circledR}$ Plant Kit from Qiagen and the Wizard ${ }^{\circledR}$ Genomic DNA Purification Kit from Promega). Many of these protocols can be time-consuming or too expensive. Yet, none of these studies have tested the applicability of their protocols for Atlantic Forest or Cerrado species. To date, we are unaware of any population genetics study carried out on these biomes that used bark as a source of DNA.

The Atlantic Forest and the Cerrado biomes are among the most biodiverse and endangered areas of the world. They have been considered two of the 34 hotspots for biodiversity conservation in a global context (Mittermeier et al., 2004). Besides, these two biomes are poorly studied and DNA-based studies are particularly scarce, especially those involving tree species. Adult trees from the Atlantic Forest can easily reach 20 to 30 meters tall (Por, 1992) and can have erect trunks that start branching just at great distances from the ground. Furthermore, many tree species from the Atlantic Forest and Cerrado are semi-deciduous or deciduous, being deprived of leaves during some months of the year.

The Leguminosae family is the third plant family in species number, with more than 18,000 species in more than 700 genera. It has great economic importance worldwide and is an important component of the main tropical vegetation communities (Lewis, 2005). Both in the Atlantic Forest and in the Cerrado, the family is one of those with the greatest number of species all over the great geographical range of these biomes (Heringer et al., 1977; Oliveira and Fontes, 2000). Several tree species from the Atlantic Forest are known for their great economic value, especially due to their timber, for example Brazilian rosewood (Dalbergia nigra), braúna (Melanoxylon brauna), vinhático (Plathymenia reticulata), and Brazilwood (Caesalpinia echinata), as well as some of the Cerrado, for example, sucupira-preta (Bowdichia virgilioides), jacarandá-do-Cerrado (Dalbergia miscolobium) and again vinhático (Souza and Lorenzi, 2008).

In this study, we describe a modified CTAB method for DNA isolation of the stem bark of Leguminosae trees from the Atlantic Forest and Cerrado biomes of South America. Details of tissue sampling, storage and the DNA isolation protocol itself are given. The applicability of the methods for 18 species was checked. The performance of the protocol was compared between leaves and bark and between dried and frozen bark. This way, we hope to provide an alternative for obtaining DNA, apart from leaves, for investigators interested in molecular studies of trees from these biomes.

\section{MATERIAL AND METHODS}

\section{Tissue sampling and storage}

Leaves and bark from the plants were collected, and the first ones were frozen at $-20^{\circ} \mathrm{C}$ while the second ones were both frozen and silica gel dried. Once dried, the bark samples were kept in refrigerators. The samples were kept under these conditions for at least one week before initial tests. Sampling was carried out during the end of the rainy season, with the exception of the bark samples from Erythrina speciosa, which were sampled during the middle of the dry season, when the species had no leaves at all.

Bark sampling was performed using a hammer and a chisel, common tools easily found in any hardware store. The chisel was hammered into the bark until reaching the 
wood of the plant, which generally offered more resistance to the chisel penetration. By doing this, we aimed to collect the inner portion of the bark, which contains the phloem (Esau, 1977). The bark thickness ranged from 0.5 to $3 \mathrm{~cm}$, and a $1 \times 1-\mathrm{cm}$ square was enough to perform one isolation procedure. After collecting the inner portion, when it was possible, the remaining tissues were put back in place to assure fast bark regeneration. In order to avoid exposure of the trees to fungal diseases, we applied a Bordeaux mixture, which consists basically of a solution of copper sulfate and calcium oxide, also known in Brazil as "Calda Bordalesa", over the wound caused by the sampling procedure.

\section{The modified CTAB method}

Initial tests for DNA isolation were carried out with the classical Doyle and Doyle (1987) method with some slight modifications, using the bark of three species, Dalbergia nigra, D. miscolobium and Plathymenia reticulata. As these tests were not successful for one of the species initially tested, we looked for improvements that could be efficient but simpler than other procedures specially designed for bark DNA isolation. In the end, we obtained a protocol that was very efficient for the three species, and this was selected for testing with the other species. The protocol was based on that of Doyle and Doyle (1987) with main modifications based on Ferreira and Grattapaglia (1995) and Colpaert et al. (2005). The final protocol is described below.

\section{Preparation of the tissue}

Before the isolation procedure, thin slices from the inner portion of the bark were cut with a razor blade and were weighed. We standardized a quantity for each kind of sample: $100 \mathrm{mg}$ for leaves, $125 \mathrm{mg}$ for frozen bark and $75 \mathrm{mg}$ for dried bark. These differences were based mainly on the amount of debris associated with each of them in the initial steps of the isolation procedure.

\section{The DNA isolation procedure}

1. Grind both tissues with mortar and pestle and liquid nitrogen until they form a fine powder. In general, grinding the bark is not difficult, being even easier than grinding leaves from some Cerrado species.

2. Immediately after thawing the samples, add $1 \mathrm{~mL}$ of a CTAB extraction buffer $[2 \%$ CTAB, 1.4 M NaCl, 100 mM Tris-HCl, pH 8.0, 20 mM EDTA, pH 8.0, PVP 2\%], $2 \%(20 \mu \mathrm{L}) 2$-mercaptoethanol and $35 \mu \mathrm{L}$ proteinase $\mathrm{K}(1 \mathrm{mg} / \mathrm{mL})$ to the powder.

3. After some more grinding, add $35 \mu \mathrm{L} 20 \% \mathrm{SDS}(\mathrm{w} / \mathrm{v})$ and mix until getting a homogeneous mixture.

4. Transfer the mixture to $2-\mathrm{mL}$ tubes. For some species, especially the dried bark, some fibers may not be disrupted. In such case, these fibers must be removed from the powder, if not, they can hinder further steps.

5. Incubate tubes for $60 \mathrm{~min}$ at $60^{\circ} \mathrm{C}$ with occasional swirling.

6. After the samples cool to the room temperature, add $600 \mu \mathrm{L} \mathrm{CIA} \mathrm{[chloroform/isoam-}$ 
yl-alcohol (24:1)] to the tubes and homogenize them by gentle inversion for $5 \mathrm{~min}$.

7. Centrifuge samples for $15 \mathrm{~min}$ at maximum speed and transfer the supernatant carefully to new $1.5-\mathrm{mL}$ tubes.

8. Add $140 \mu \mathrm{L} 10 \% \mathrm{CTAB}(\mathrm{w} / \mathrm{v}$ ) and $280 \mu \mathrm{L} 5 \mathrm{M} \mathrm{NaCl}$ and, by gentle inversion, mix until homogenization.

9. Repeat steps 6 and 7.

10. Precipitate DNA by the addition of 1 volume of cold isopropanol and incubate tubes overnight at $-20^{\circ} \mathrm{C}$.

11. Centrifuge for $10 \mathrm{~min}$ at maximum speed and discard the supernatant.

12. Wash the pellet 2-3 times with cold $70 \%$ ethanol (v/v).

13. After the last discard, dry the pellet (usually $15 \mathrm{~min}$ at $37^{\circ} \mathrm{C}$ is enough), and then dissolve it in $30 \mu \mathrm{L}$ TE buffer [10 mM Tris- $\mathrm{HCl}, \mathrm{pH}$ 8.0, $1 \mathrm{mM}$ EDTA, $\mathrm{pH}$ 8.0] with $10 \mu \mathrm{g} / \mathrm{mL}$ RNAse A for $2 \mathrm{~h}$ at $37^{\circ} \mathrm{C}$.

\section{DNA quantification}

DNA quantification and quality assessment were performed by visualization of products on agarose gels and by spectrophotometry. An aliquot of $1 \mu \mathrm{L}$ of total genomic DNA was used in the spectrophotometer NanoDrop ${ }^{\mathrm{TM}}$ (NanoDrop Technologies) according to manufacturer instructions. Two measurements were taken: the absorbance at 260 $\mathrm{nm}$, which reflects the DNA concentration, and the ratio of the absorbances at 260 and $280 \mathrm{~nm}\left(\mathrm{~A}_{260} / \mathrm{A}_{280}\right.$ ratio), which reflects the ratio of nucleic acids to proteins in the sample (Sambrook and Russell, 2001).

\section{DNA amplification}

The suitability of the DNA obtained for polymerase chain reactions (PCR) was tested by the amplification of two widely used regions from the chloroplast and nuclear genomes, the $p s b A-t r n H$ and the internal transcribed spacer region of the rRNA DNA, respectively. Primers used for $p s b A$-trnH and internal transcribed spacer regions were respectively trn H (GUG) and psb A described by Hamilton (1999) and CY1 and CY3 described by Wright et al. (2006). PCR conditions and cycles were the same as those used by Ribeiro et al. (2007). Only dried bark and leaves were used for PCR tests.

\section{Species tested}

Eighteen tree species of the Leguminosae family were selected for the tests with the DNA isolation protocol, fourteen of them occurring in the Atlantic Forest biome, three in the Cerrado biome, and one in both biomes (Table 1). Selected species comprise all three subfamilies (and also the informal Cercidae) and are widespread across a recent Leguminosae phylogeny (Wojciechowski et al., 2004), with representatives of the majority of the main clades. In this manner, we aimed to obtain results that could probably be extended to other species of the family. Two individuals were tested for the majority of the species, with the exception for Bowdichia virgilioides, Dimorphandra mollis and Holocalyx balansae, allowing us to test the reproducibility of the results. 


\begin{tabular}{lc} 
Table 1. Species tested and their biomes of occurrence. & \\
\hline Species & \\
\hline Caesalpinioideae & Occurrence in Atlantic Forest and Cerrado \\
Bauhinia longifolia D. Dietr. & Atlantic Forest \\
Caesalpinia pluviosa DC. & Atlantic Forest \\
Hymenaea courbaril L. & Atlantic Forest \\
Melanoxylon brauna Schott & Atlantic Forest \\
Senna multijuga (Rich.) H.S. Irwin \& Barneby & Atlantic Forest \\
Mimosoideae & \\
Anadenanthera peregrina (L.) Speg. & Atlantic Forest \\
Dimorphandra mollis Benth. & Cerrado \\
Piptadenia gonoacantha (Mart.) J.F. Macbr. & Atlantic Forest \\
Plathymenia reticulata Benth. & Atlantic Forest and Cerrado \\
Papilionoideae & Cerrado \\
Bowdichia virgilioides Kunth & Atlantic Forest \\
Centrolobium tomentosum Guillemin ex Benth. & Cerrado \\
Dalbergia miscolobium Benth. & Atlantic Forest \\
Dalbergia nigra (Vell.) Alemao ex Benth. & Atlantic Forest \\
Erytrina speciosa Andrews & Atlantic Forest \\
Holocalyx balansae Micheli & Atlantic Forest \\
Machaerium aculeatum Raddi & Atlantic Forest \\
Myroxylon peruiferum L.f. & Atlantic Forest \\
Platycyamus regnelli Benth. & \\
\hline
\end{tabular}

\section{RESULTS AND DISCUSSION}

Together, the three steps for DNA isolation from bark, sampling the tissue, its storage in two different ways and the DNA isolation protocol described were very successful. It was possible to obtain enough DNA of satisfactory quality from the bark of all eighteen species tested. The amount of DNA obtained in relation to the amount of tissue used was very high, ranging from 70 to more than $3000 \mathrm{ng} / \mu \mathrm{L}$, which corresponds to 20 to $850 \mathrm{ng}$ DNA for each milligram of dry tissue used, and an average of $310 \mathrm{ng} / \mathrm{mg}$ (Table 2). The DNA obtained for Dalbergia miscolobium was a bit brownish and could not be analyzed by spectrophotometry, but it could be done by electrophoresis (Figure 1). The quality of the DNA was high for most of the species, with $81 \%$ of the samples with an $\mathrm{A}_{260} / \mathrm{A}_{280}$ ratio above the optimal limit of 1.8 (Sambrook and Russell, 2001). In general, leaves yielded higher quantities of DNA than bark, but there were some exceptions (Table 2). The DNA quality, in contrast, was in general comparable between leaves and bark. This enables the use of bark as an alternative as good as leaves for obtaining DNA.

For two species, Dimorphandra mollis and Senna multijuga, the protocol only was efficient with the bark samples. The mixtures obtained from leaves after the third step of the protocol were too viscous, indicating high amounts of polysaccharides. Indeed, DNA isolation from leaves of D. mollis is known to be difficult (Souza HAV, personal communication). This result shows that for some species, using the bark could be preferable even when the leaves are easily accessible. D. mollis, for example, is a Cerrado species, and although its leaves are generally reachable by hand, sampling the bark could be a better choice to obtain higher quality DNA.

Differences were not observed between the dried and the frozen barks, making both kinds of storage equally satisfactory for bark DNA isolation. We did not test the storage of the tissues in CTAB buffer as this storage makes the field procedures a little more laborious, since pre-preparation of the buffer is needed. In addition, Colpaert et al. (2005) reported that, for their protocol, 
tissues stored in CTAB buffer yielded less DNA than those silica dried. Our results provide two simple and efficient ways to store the bark: frozen and dried in silica gel. The choice between these two procedures can therefore be made according to the available resources of each field work.

\begin{tabular}{|c|c|c|c|c|c|}
\hline Species & Tissue & DNA conc. $(\mathrm{ng} / \mu \mathrm{L})$ & Yield (ng/mg) & DNA quality $\left(\mathrm{A}_{260} / \mathrm{A}_{280}\right.$ ratio $)$ & PCR amplification \\
\hline \multirow[t]{3}{*}{ Anadenanthera peregrina } & $\mathrm{L}$ & 643.2 & 214.4 & 1.96 & $\mathrm{C} / \mathrm{N}$ \\
\hline & $\mathrm{fB}$ & 611.0 & 166.6 & 2.01 & $\mathrm{n} / \mathrm{a}$ \\
\hline & $\mathrm{dB}$ & 364.0 & 72.8 & 1.96 & $\mathrm{C} / \mathrm{N}$ \\
\hline \multirow[t]{3}{*}{ Bauhinia longifolia } & $\mathrm{L}$ & 1035.2 & 345.1 & 2.02 & $\mathrm{C} / \mathrm{N}$ \\
\hline & $\mathrm{fB}$ & 660.9 & 180.2 & 1.83 & $\mathrm{n} / \mathrm{a}$ \\
\hline & $\mathrm{dB}$ & 758.3 & 151.7 & 1.94 & $\mathrm{C} / \mathrm{N}$ \\
\hline \multirow[t]{3}{*}{ Bowdichia virgilioides } & $\mathrm{L}$ & 1726.8 & 575.6 & 1.87 & $\mathrm{C} / \mathrm{N}$ \\
\hline & $\mathrm{fB}$ & 1751.4 & 477.7 & 1.34 & $\mathrm{n} / \mathrm{a}$ \\
\hline & $\mathrm{dB}$ & 1802.9 & 360.6 & 1.32 & $\mathrm{C} / \mathrm{N}$ \\
\hline \multirow{3}{*}{ Caesalpinia pluviosa } & $\mathrm{L}$ & 1287.0 & 429.0 & 1.83 & $\mathrm{C} / \mathrm{N}$ \\
\hline & $\mathrm{fB}$ & 1436.3 & 391.7 & 1.64 & $\mathrm{n} / \mathrm{a}$ \\
\hline & $\mathrm{dB}$ & 1209.1 & 241.8 & 1.90 & $\mathrm{C} / \mathrm{N}$ \\
\hline \multirow[t]{3}{*}{ Centrolobium tomentosum } & $\mathrm{L}$ & 2564.0 & 854.7 & 1.74 & $\mathrm{C} / \mathrm{N}$ \\
\hline & $\mathrm{fB}$ & 992.8 & 270.8 & 1.49 & $\mathrm{n} / \mathrm{a}$ \\
\hline & $\mathrm{dB}$ & 1605.5 & 321.1 & 1.22 & $\mathrm{C} / \mathrm{N}$ \\
\hline \multirow{3}{*}{ Dimorphandra mollis } & $\mathrm{L}$ & - & - & - & $-/-$ \\
\hline & $\mathrm{fB}$ & 704.6 & 192.2 & 1.91 & $\mathrm{n} / \mathrm{a}$ \\
\hline & $\mathrm{dB}$ & 415.5 & 83.1 & 1.89 & $\mathrm{C} / \mathrm{N}$ \\
\hline \multirow[t]{3}{*}{ Dalbergia miscolobium } & $\mathrm{L}$ & 1187.9 & 396.0 & 1.87 & $\mathrm{C} / \mathrm{N}$ \\
\hline & $\mathrm{fB}$ & $\mathrm{n} / \mathrm{a}$ & $\mathrm{n} / \mathrm{a}$ & $\mathrm{n} / \mathrm{a}$ & $\mathrm{n} / \mathrm{a}$ \\
\hline & $\mathrm{dB}$ & $\mathrm{n} / \mathrm{a}$ & $\mathrm{n} / \mathrm{a}$ & $\mathrm{n} / \mathrm{a}$ & $\mathrm{C} / \mathrm{N}$ \\
\hline \multirow{3}{*}{ Dalbergia nigra } & $\mathrm{L}$ & 2413.5 & 804.5 & 1.95 & $\mathrm{C} / \mathrm{N}$ \\
\hline & $\mathrm{fB}$ & 750.6 & 204.7 & 1.96 & $\mathrm{n} / \mathrm{a}$ \\
\hline & $\mathrm{dB}$ & 707.8 & 141.6 & 1.90 & $\mathrm{C} / \mathrm{N}$ \\
\hline \multirow[t]{3}{*}{ Erythrina speciosa } & $\mathrm{L}$ & 1582.6 & 527.5 & 1.98 & $\mathrm{C} / \mathrm{N}$ \\
\hline & $\mathrm{fB}$ & 1041.0 & 283.9 & 1.90 & $\mathrm{n} / \mathrm{a}$ \\
\hline & $\mathrm{dB}$ & 1332.5 & 266.5 & 1.96 & $\mathrm{C} / \mathrm{N}$ \\
\hline \multirow{3}{*}{ Holocalyx balansae } & $\mathrm{L}$ & 1934.8 & 644.9 & 1.95 & $\mathrm{C} / \mathrm{N}$ \\
\hline & $\mathrm{fB}$ & 763.4 & 208.2 & 1.90 & $\mathrm{n} / \mathrm{a}$ \\
\hline & $\mathrm{dB}$ & 2194.3 & 438.9 & 1.96 & $\mathrm{C} / \mathrm{N}$ \\
\hline \multirow{3}{*}{ Hymenaea courbaril } & $\mathrm{L}$ & 889.7 & 296.6 & 1.99 & $\mathrm{C} / \mathrm{N}$ \\
\hline & $\mathrm{fB}$ & 724.6 & 197.6 & 1.95 & $\mathrm{n} / \mathrm{a}$ \\
\hline & $\mathrm{dB}$ & 642.0 & 128.4 & 1.98 & $\mathrm{C} / \mathrm{N}$ \\
\hline \multirow[t]{3}{*}{ Machaerium aculeatum } & $\mathrm{L}$ & 1763.2 & 587.7 & 1.97 & $\mathrm{C} / \mathrm{N}$ \\
\hline & $\mathrm{fB}$ & 420.8 & 114.8 & 1.92 & $\mathrm{n} / \mathrm{a}$ \\
\hline & $\mathrm{dB}$ & 843.9 & 168.8 & 1.90 & $\mathrm{C} / \mathrm{N}$ \\
\hline \multirow[t]{3}{*}{ Melanoxylon brauna } & $\mathrm{L}$ & 862.1 & 287.4 & 1.89 & $\mathrm{C} / \mathrm{N}$ \\
\hline & $\mathrm{fB}$ & 555.3 & 151.4 & 2.04 & $\mathrm{n} / \mathrm{a}$ \\
\hline & $\mathrm{dB}$ & 742.0 & 148.4 & 1.92 & $\mathrm{C} / \mathrm{N}$ \\
\hline \multirow[t]{3}{*}{ Myroxylon peruiferum } & $\mathrm{L}$ & 3177.1 & 1059.0 & 1.95 & $\mathrm{C} / \mathrm{N}$ \\
\hline & $\mathrm{fB}$ & 1636.9 & 446.4 & 1.92 & $\mathrm{n} / \mathrm{a}$ \\
\hline & $\mathrm{dB}$ & 1666.6 & 333.3 & 1.96 & $\mathrm{C} / \mathrm{N}$ \\
\hline \multirow[t]{3}{*}{ Piptadenia gonoacantha } & $\mathrm{L}$ & 973.4 & 324.5 & 1.99 & $\mathrm{C} / \mathrm{N}$ \\
\hline & $\mathrm{fB}$ & 379.1 & 103.4 & 1.86 & $\mathrm{n} / \mathrm{a}$ \\
\hline & $\mathrm{dB}$ & 284.9 & 57.0 & 1.78 & $\mathrm{C} / \mathrm{N}$ \\
\hline \multirow{3}{*}{ Platycyamus regnelli } & $\mathrm{L}$ & 1426.9 & 475.6 & 2.01 & $\mathrm{C} / \mathrm{N}$ \\
\hline & $\mathrm{fB}$ & 794.5 & 216.7 & 2.01 & $\mathrm{n} / \mathrm{a}$ \\
\hline & $\mathrm{dB}$ & 1231.2 & 246.2 & 2.06 & $\mathrm{C} / \mathrm{N}$ \\
\hline \multirow[t]{3}{*}{ Plathymenia reticulata } & $\mathrm{L}$ & 662.5 & 220.8 & 1.92 & $\mathrm{C} / \mathrm{N}$ \\
\hline & $\mathrm{fB}$ & 69.9 & 19.1 & 1.16 & $\mathrm{n} / \mathrm{a}$ \\
\hline & $\mathrm{dB}$ & 99.6 & 19.9 & 1.57 & $\mathrm{C} / \mathrm{N}$ \\
\hline \multirow{3}{*}{ Senna multijuga } & $\mathrm{L}$ & - & - & - & $\mathrm{C} / \mathrm{N}$ \\
\hline & $\mathrm{fB}$ & 1662.8 & 453.5 & 2.06 & $\mathrm{n} / \mathrm{a}$ \\
\hline & $\mathrm{dB}$ & 1037.3 & 207.5 & 2.00 & $\mathrm{C} / \mathrm{N}$ \\
\hline
\end{tabular}

$\mathrm{L}=$ leaf; $\mathrm{fB}=$ frozen bark; $\mathrm{dB}=$ dried bark. For polymerase chain reaction $(\mathrm{PCR})$ amplification, letters indicate successful amplification: $\mathrm{C}$ for the plastid region and $\mathrm{N}$ for the nuclear. $\mathrm{n} / \mathrm{a}=$ not applicable. Yield was calculated based on the dry mass of the tissues. When two individuals were tested for one species, result is the mean value obtained. 


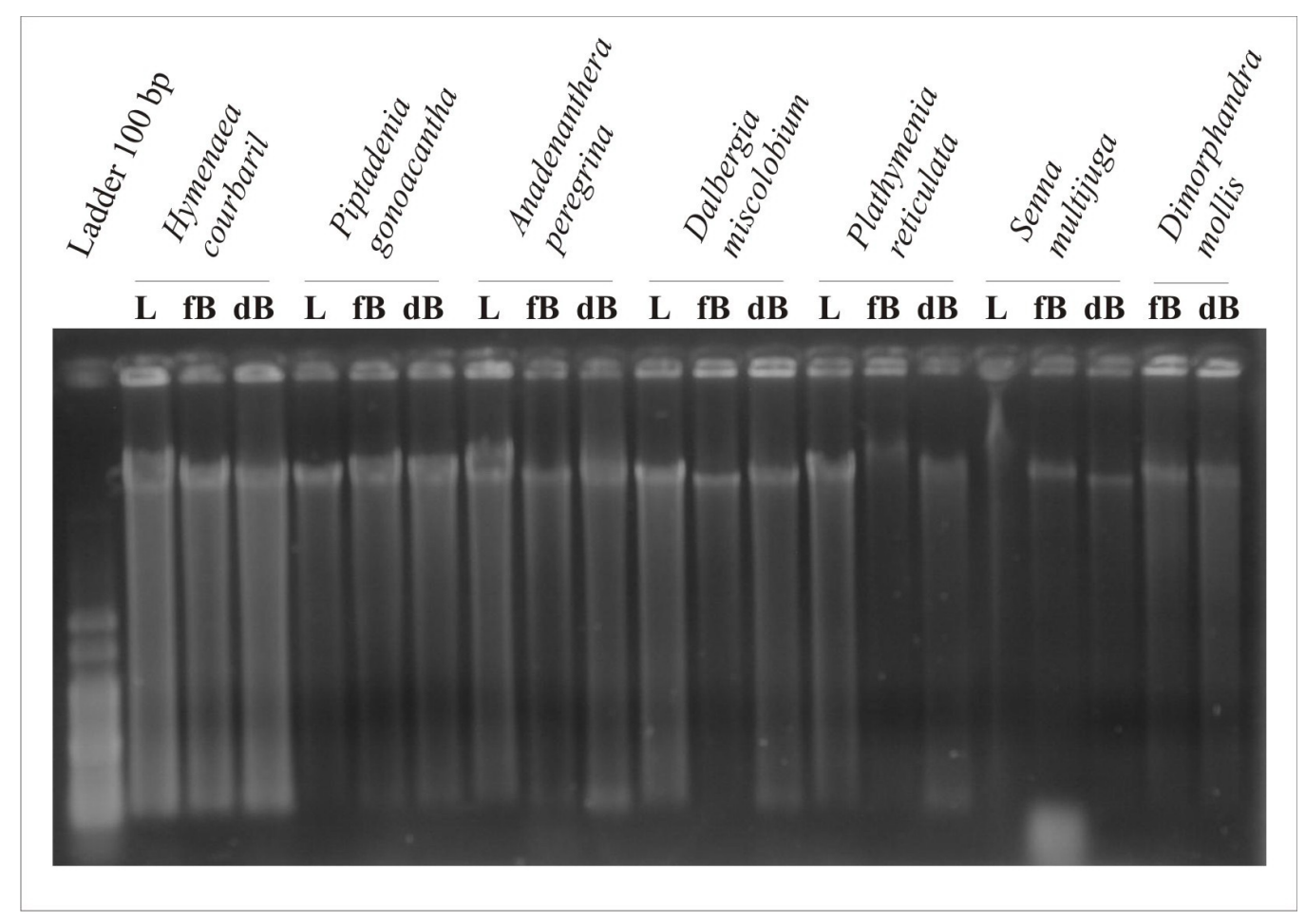

Figure 1. Total genomic DNA. $\mathrm{L}=$ leaf; $\mathrm{fB}=$ frozen bark; $\mathrm{dB}=$ dried bark.

For one species, Erythrina speciosa, the bark was sampled during the dry season, when the plants did not have any leaves at all. However, large amounts of DNA of good quality could be obtained from it, and these were comparable to those obtained from the leaves sampled at the end of the rainy season (Table 2). This result shows that the bark of this species can offer high-quality DNA even in the dry season with the absence of leaves. Therefore, at least for this species, sampling would be possible all year long, even when the leaves are absent or in poor condition, making field trip scheduling more flexible. This could also be true for the other species tested, but tests are recommended before extensive sampling is made.

PCR performed for both genomic regions was successful in producing strong bands for all the samples tested (Figure 2), with the only exception for leaves from Dimorphandra mollis. This demonstrates that the DNA obtained was pure enough to be suitable for PCR amplifications of plastid and nuclear DNA. These regions are commonly used in plant population genetics and phylogenetics studies and the plastid region was among the four regions pre-selected as a potential barcode for land plants (Chase et al., 2007).

Some considerations are important when dealing with bark tissues. First, the freezing of the bark did not need to be done immediately in the field. For Plathymenia reticulata and Dalbergia nigra, the tissues could be maintained for four days in sealed coolers with ice or in refrigerators. Once in the laboratory, they were kept at $-20^{\circ} \mathrm{C}$ and the DNA isolation performed well. Second, with regard to silica gel storage, special attention had to be given to the satura- 
tion of the silica. Bark tissues can be rich in sap and therefore in carbohydrates, soluble sugars and water content. This makes these tissues ideal environments for fungal development, and a few days without proper silica gel replacement were enough to lose the entire sample. Therefore, either a large quantity of silica or more than two replacements are sometimes needed to dry the tissue completely. Finally, slight differences in the portion of the bark sampled can result in significant differences in the DNA obtained. In initial tests, we compared the inner, the middle and the outer portions of the bark, and significantly more DNA was obtained from the first one (data not shown). Therefore, correct sampling could be crucial to the success of the DNA isolation, and attention must be given to this step.

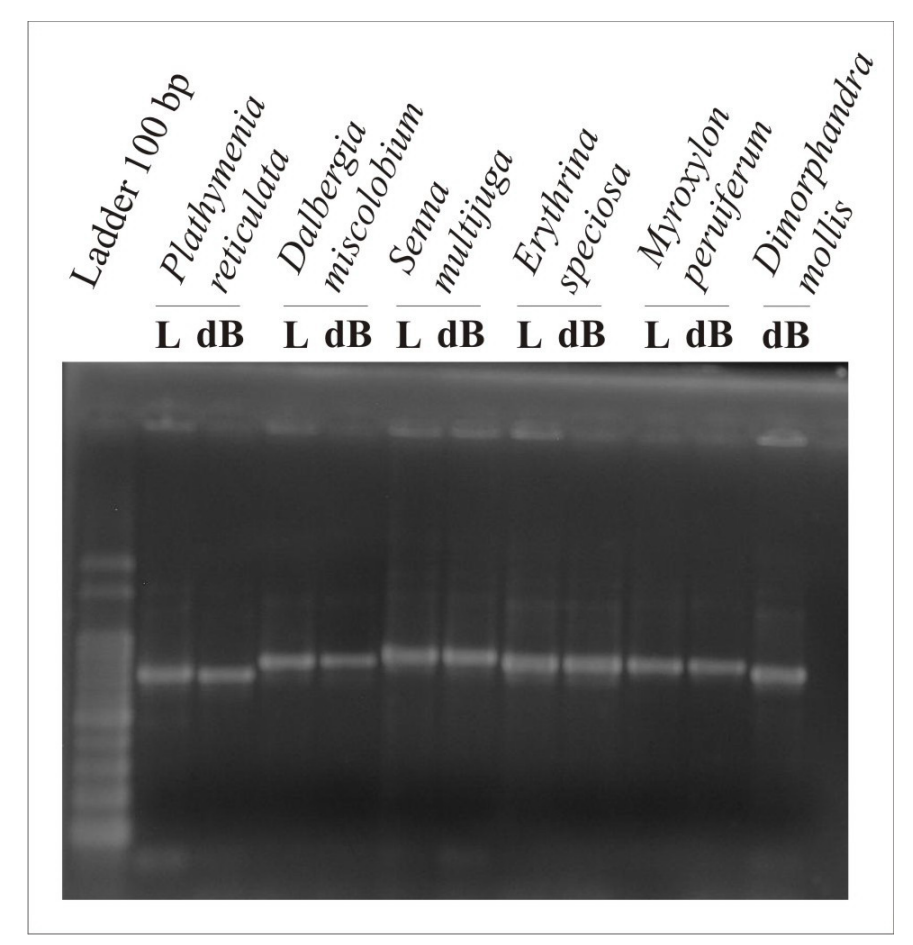

Figure 2. Amplification of the internal transcribed spacer region. $\mathrm{L}=$ leaf; $\mathrm{dB}=$ dried bark.

Our protocol proved to be a simple, fast, relatively inexpensive, and effective method for DNA isolation from leaves and from dried and frozen bark tissues from Leguminosae trees from the Atlantic Forest and Cerrado. The Leguminosae family is a very diverse group both in terms of species and phytochemicals (Wink and Mohamed, 2003). Our protocol could successfully extract DNA from a wide range of Leguminosae species, which make us believe it would be suitable for other legume species, species of other families, and species from other biomes as well. Nevertheless, even species closely related to each other can have a great variability in their biochemical composition (Rachmayanti et al., 2006). Thus, the result of the protocol could be, to some degree, particular for each species, and previous tests for other species are recommended before adopting it as a routine laboratory procedure. 
In this paper, we provided different alternatives of sampling for investigators interested in conducting molecular studies in populations of Leguminosae trees from the Atlantic Forest and Cerrado. In the field, researchers can easily sample a larger number of individuals with simple materials in a shorter time. These results can also make field trip planning easier since they provide some independence from specialized crew such as climbers, or equipment such as tree pruners or firearms, or costs associated with them. Finally, sampling can be carried out during periods when leaves are in poor condition, as in the dry season for deciduous species, and also when the integrity of leaves is affected by predators or diseases.

\section{ACKNOWLEDGMENTS}

We are grateful to Bruno V. Souza and Vinícius M. Miranda for their technical assistance and Élder A. S. Paiva for precious advice in plant anatomy. We also thank Marcos Sobral, Luciana H.Y. Kamino and José P. Lemos-Filho for their help in species identification. Finally, we are thankful to PELD/CNPq and FAPEMIG for financial support.

\section{REFERENCES}

Avise JC (2000). Phylogeography: The History and Formation of Species. Harvard University Press, Cambridge.

Chase MW, Cowan RS, Hollingsworth PM, van den Berg C, et al. (2007). A proposal for a standardised protocol to barcode all land plants. Taxon 56: 295-299.

Coley PD and Barone JA (1996). Herbivory and plant defenses in tropical forests. Annu. Rev. Ecol. Syst. 27: 305-335.

Colpaert N, Cavers S, Bandou E, Caron H, et al. (2005). Sampling tissue for DNA analysis of trees: trunk cambium as an alternative to canopy leaves. Silvae Genet. 54: 265-269.

Crawford DJ (2000). Plant macromolecular systematics in the past 50 years: one view. Taxon 49: 479-490.

Csaikl UM, Bastian H, Brettschneider R, Gauch S, et al. (1998). Comparative analysis of different DNA extraction protocols: a fast, universal maxi-preparation of high quality plant DNA for genetic evaluation and phylogenetic studies. Plant Mol. Biol. Rep. 16: 69-86.

Doyle JJ and Doyle JL (1987). A rapid DNA isolation procedure for small quantities of fresh leaf tissue. Phytochem. Bull. 19: 11-15.

Esau K (1977). Anatomy of Seed Plants. Wiley, New York.

Fang G, Hammar S and Grumet R (1992). A quick and inexpensive method for removing polysaccharides from plant genomic DNA. Biotechniques 13: 52-54, 56.

Ferreira ME and Grattapaglia D (1995). Introdução ao Uso de Marcadores Moleculares em Análise Genética. EMBRAPACENARGEN, Brasília.

Hamilton MB (1999). Four primer pairs for the amplification of chloroplast intergenic regions with intraspecific variation. Mol. Ecol. 8: 521-523.

Heringer EP, Barroso GM, Rizzo JA and Rizzini CT (1977). A Flora do Cerrado. In: Anais do IV Simpósio sobre o Cerrado. Livraria Itatiaia Editora, Belo Horizonte.

Ivanova NV, Fazekas AJ and Hebert PDN (2008). Semi-automated, membrane-based protocol for DNA isolation from plants. Plant Mol. Biol. Rep. 26: 186-198.

Lewis GP (2005). Legumes of the World. Royal Botanic Gardens, Richmond.

Mittermeier RA, Gil PR, Hoffmann J, Pilgrim J, et al. (2004). Hotspots Revisited: Earth’s Biologically Richest and Most Endangered Terrestrial Ecoregions. Cemex, Conservation International and Agrupacion Sierra Madre, Monterrey.

Oliveira AT and Fontes MAL (2000). Patterns of floristic differentiation among Atlantic forests in southeastern Brazil and the influence of climate. Biotropica 32: 793-810.

Pandey RN, Adams RP and Flournoy LE (1996). Inhibition of random amplified polymorphic DNAs (RAPDs) by plant polysaccharides. Plant Mol. Biol. Rep. 14: 17-22.

Por FD (1992). Sooretama: the Atlantic Rain Forest of Brazil. SPB Academic Publishing, The Hague.

Rachmayanti Y, Leinemann L, Gailing O and Finkeldey R (2006). Extraction, amplification and characterization of wood DNA from Dipterocarpaceae. Plant Mol. Biol. Rep. 24: 45-55. 
R.M.L. Novaes et al.

Ribeiro RA and Lovato MB (2007). Comparative analysis of different DNA extraction protocols in fresh and herbarium specimens of the genus Dalbergia. Genet. Mol. Res. 6: 173-187.

Ribeiro RA, Lavin M, Lemos JP, Mendonça Filho CV, et al. (2007). The genus Machaerium (Leguminosae) is more closely related to Aeschynomene sect. Ochopodium than to Dalbergia: inferences from combined sequence data. Syst. Bot. 32: 761-771.

Rogers, SO and Bendich AJ (1985). Extraction of DNA from milligram amounts of fresh, herbarium and mummified plant tissues. Plant. Mol. Biol. 5: 69-76.

Sambrook J and Russell DW (2001). Molecular Cloning: a Laboratory Manual. Cold Spring Harbor Laboratory Press, New York.

Souza VC and Lorenzi H (2008). Botânica Sistemática: Guia Ilustrado para Identificação das Famílias de Fanerógamas Nativas e Exóticas no Brasil, Baseado em APG II. Instituto Plantarum de Estudos da Flora, Nova Odessa.

Tibbits JFG, McManus LJ, Spokevicius AV and Bossinger G (2006). A rapid method for tissue collection and highthroughput isolation of genomic DNA from mature trees. Plant Mol. Biol. Rep. 24: 81-91.

Wink M and Mohamed GIA (2003). Evolution of chemical defense traits in the Leguminosae: mapping of distribution patterns of secondary metabolites on a molecular phylogeny inferred from nucleotide sequences of the rbcL gene. Biochem. Syst. Ecol. 31: 897-917.

Wojciechowski MF, Lavin M and Sanderson MJ (2004). A phylogeny of legumes (Leguminosae) based on analysis of the plastid $m a t K$ gene resolves many well-supported subclades within the family. Am. J. Bot. 91: 1846-1862.

Wright S, Keeling J and Gillman L (2006). The road from Santa Rosalia: a faster tempo of evolution in tropical climates. Proc. Natl. Acad. Sci. U. S. A. 103: 7718-7722. 